Dr Yam Bahadur Roka

MS, M.Ch., IFAANS

Address for correspondence:

Senior Consultant and Head

Department of Neurosurgery

Neuro Cardio and Multi Specialty hospital,

Biratnagar, Nepal

dryamroka@yahoo.com

Date submitted: $15 / 03 / 2018$

Date accepted: $20 / 04 / 2018$

Fédération Internationale de FootballAssociationWorld (FIFA) cup 2018 is over and there are other sports competitions which are happening almost every day in different parts of the world in different- countries, level, age, gender, type and duration. Some of the major incidents of head injury during this FIFA 2018 are, Peru's Renato Tapia was knocked flat against Denmark, allowed to play to be substituted 13 minutes later, Morocco's NordinAmrabat suffered concussion and memory loss following a blow to the head against Portugal, Iceland defender Ragnar Sigurdsson went down being struck in the back of the head against Nigeria, playing with a bandage and then substituted in the 65th minute and Peru's Jefferson Farfan was left temporarily paralyzed during the World Cup training.

Injuries related to sports are mainly seen in hockey, football, rugby, basketball, cycling, boxing, snowboarding, horse riding and soccer.One of the common problems faced during sports is concussion and hence this article aims to define its epidemiology, pathophysiology and management along with a short review of literature.

Concussion in sports (CIS) is a common type of injury related to sports which must be recognized and treated quickly with a decision whether the sportsperson can return to play or not. ${ }^{2}$ The simplest definition of CIS will be trauma leading to symptoms of mild head injury. This definition will though not tell of any internal injuries, future neuro-psychological problems or any other future complications. The earliest description of concussion was done by the Persian Physician Rhazes who defined transient neurological syndrome secondary to head shaking. ${ }^{23}$ There are now many studies and scales available in literature that have defined the severity of concussion many of which have not been scientifically proven. ${ }^{16}$ It is well known now that the symptoms causing CIS varies from different individuals and the type of injury and its effect too depends on the kinetics of the brain movement inside in relation with the fixed structures like bone and dura. Many different articles

\section{Concussion Injury In Sports: Brief Review Of The Epidemiology And Initial Management}

have investigated the characteristics of CIS in relation to mild head injury and the type of sports with different bodies having different methods of diagnosis and criteria for further play (Figure 1). ${ }^{15,20}$

Definition and Epidemiology: Concussion is defined by Merriam-Webster dictionary as, a: a stunning, damaging, or shattering effect from a hard blow; especially: a jarring injury of the brain resulting in disturbance of cerebral function.b: a hard blow or collision. It means to "shake violently" from the Latin word Concutere. In the USA alone around 3.8 million concussions are reported each year and the many still go unreported. Concussion can occur in upto $14 \%$ of all sports related injuries with 700,000 concussion between $2005-2010$ and $13 \%$ of them being recurrent concussion. ${ }^{5}$ It is more common in female sports, younger age, and in actual matches than during training and certain type of sports as stated above. ${ }^{10,21}$ in males its due to player to player contact injury and in females due to trauma by fall, equipment or surface. ${ }^{6}$ Most of the symptoms last less than 72 hours and the majority will resolve within a week and brief loss of consciousness or seizure may not lead to delay in recovery. ${ }^{4}$ The majority $(80 \%)$ will be asymptomatic within 10 days and the rest may exhibit symptoms for few weeks.

Pathophysiology: Unlike head injury direct impact to the head is not needed for concussion which is caused by rotational and angular forces leading to neuronal disruption leading to potassium efflux, release of calcium and excitatory amino acids leading to paradoxical blood flow. ${ }^{14,18}$ This leads to neuronal injury that may persist for weeks and hence delaying the recovery of the patient. Studies have shown that mild head injuries can lead to increases in hyperphosphorylated paired helical filament 1 tau in the hippocampus that produces long term behavioral deficits. ${ }^{8}$ Another study showed that a panel of biomarkers, increases in NF-L and Tau markers, TNF $\alpha$ and IL8 markers, [SYP]CD11b+/[CD81]CD11b+, have the potential to surrogate chronic neural damage in CIS. ${ }^{12,27}$ 


\section{Roka et al}

Diagnosing CIS: The first step is to make the diagnosis of concussion which will help in early recovery, risk of further complications, reduce other musculoskeletal injuries, and other neurological or psychiatric illness. Due to the lack of a proper clinical or diagnostic pattern it is often a clinical diagnosis. ${ }^{19} \mathrm{CIS}$ diagnosis will depend on the severity of the injury, the complains by the athlete and the signs seen by the attending medical person. The common symptoms are given in Table 1.

\section{Common symptoms of concussion \\ Confusion \\ Slurred speech \\ Headache \\ Clumsiness \\ Blurring of vision \\ Nausea \\ Disorientation \\ Inappropriate behavior or response \\ Memory loss \\ Lack of concentration \\ Tinnitus \\ Convulsions \\ Decreased or increased sleep \\ Sadness \\ Depression \\ Anxiety/nervousness \\ Vacant stare \\ Fatigue}

Table 1: Some of the common symptoms of concussion.

Concussion can also be defined as mild, moderate or severe. Grade 1 concussion, symptoms last for less than 15 minutes. There is no loss of consciousness.Grade 2 concussion, there is no loss of consciousness but symptoms last longer than 15 minutes.Grade 3 concussion, the person loses consciousness, sometimes just for a few seconds.A history of CIS is associated with sustaining another concussion and the number of CIS, children and adolescents, duration or Grade and severity often will prolong the recovery. Other factors like headache more than 60 hours, presence of more than three symptoms are associated with prolonged recovery.

The initial examination starts with airway, breathing and circulation followed by cervical spine injury assessment. Most of these findings are normal in CIS and may need some form of assessment form to rule out severe concussion. The athlete must be barred from return to play till concussion is ruled out.

\section{Signs of concussion and check tools:}

\section{Assessment tools:}

There is no single method to diagnose CIS and in literature there are many tools that have been described. The following Table gives the presently available tools (Table 2). ${ }^{26}$

\section{Management of CIS}

\section{Sport-specific challenges for CIS}

Second impact injury: this was first described by Schneider in 1973 and then used in an example of a football player who died with no apparent trauma but had sustained a injury 4 days earlier by Saunders and Harbaugh. ${ }^{24,25}$ classically the athlete suffers a concussion and before the symptoms resolve they return to the sport during which they suffer a relatively minor trivial injury. This lead to a stunned athlete who can resume the play but then suddenly they collapse with dilated pupils and respiratory failure. Pathologically it is due to cerebrovascular dysregulation with edema and herniation. This term means that a person is prone to repeated concussion after the first injury and hence must be carefully observed and prevented to play, to prevent further complications.

\section{Using video in CIS}

With the use of more and more technology in sports it is common to find and record an impact or injury that can be replayed again and again to study the nature of the severity of injury. Application of such in sports has led to the better understanding od CIS which can allow to individual or organizational policy making and management. Although video recording helps one must still understand its limitations in recording, showing the angle of impact or response from the athletes. ${ }^{13}$

The initial examination will either confirm or rule out CIS and hence the athlete can either return to play/ home care with observation or will need further medical attention in a hospital. Rest is the most important prevention and precaution to be taken in CIS. In case of Grade 2, 3 concussion the athlete needs to be taken to a medical center with neurosurgical facilities. Repeated waking up is controversial in the detection of CIS. ${ }^{9}$ Some patients may need neuroimaging to further diagnose severe head injury the guidelines of which have been laid down by the American College of Emergency Physicians, American academy of pediatrics and the American association of family physicians (Table 3 ). ${ }^{11,26,28}$

Table 3. The present guidelines for neuroimaging in concussion from American association of family physicians, American Academy of Pediatrics and the American Academy of Family Physicians. ${ }^{11,26,18}$ 


\begin{tabular}{|c|c|}
\hline Type / examples & Characteristics \\
\hline $\begin{array}{l}\text { Symptom checklists } \\
\text { Postconcussion Symptom Scale } \\
\text { Graded Symptom Checklist } \\
\text { Head Injury Scale } \\
\text { McGill Abbreviated Concussion Evaluation (ACE) } \\
\text { postconcussion symptom scale } \\
\text { HeadMinder } \\
\text { Concussion Symptom Inventory }\end{array}$ & $\begin{array}{l}\text { The most commonly used type of concussion } \\
\text { assessment tool } \\
\text { Quick, easy, cost-effective tool with good sensitivity; } \\
\text { allows athletes to self-report symptoms } \\
\text { - Cautions: symptoms may be delayed, may not be } \\
\text { reported, or were already present at baseline } \\
\text { Most checklists developed using clinical judgment; } \\
\text { the Concussion Symptom Inventory is the only } \\
\text { empirically derived symptom checklist }\end{array}$ \\
\hline $\begin{array}{l}\text { Neuropsychological tests } \\
\text { Written } \\
\text { Trail Making Test } \\
\text { Digit Symbol Substitution Test } \\
\text { Controlled Oral Word Association Test } \\
\text { Hopkins Verbal Learning Test } \\
\text { Stroop Color and Word Test } \\
\text { Computer-based } \\
\text { HeadMinder } \\
\text { CogSport } \\
\text { ImPACT } \\
\text { Automated Neuropsychological Assessment Metrics }\end{array}$ & $\begin{array}{l}\text { Designed to identify subtle cognitive deficits } \\
\text { Written tests are labor intensive and must be } \\
\text { interpreted, whereas computer-based tests can } \\
\text { be administered rapidly and to multiple patients } \\
\text { simultaneously } \\
\text { Results best interpreted when compared with baseline } \\
\text { data; affected by psychiatric disorders, physical } \\
\text { symptoms, cultural factors, and motivation/effort } \\
\text { These tests are not validated, and no data demonstrate } \\
\text { that they affect outcomes when used to guide return to } \\
\text { play } \\
\text { There are limited baseline data in children younger } \\
\text { than } 12 \text { years; child-specific computerized tests are } \\
\text { under development }\end{array}$ \\
\hline $\begin{array}{l}\text { Postural stability testing } \\
\text { BESS (and modified version } \\
\text { SOT }\end{array}$ & $\begin{array}{l}\text { - Very sensitive for concussion diagnosis, but there are } \\
\text { limited data regarding its use in monitoring recovery } \\
\text { SOT is the preferred test, but it is not portable; BESS } \\
\text { is inexpensive and easy to administer on the sideline } \\
\text { of a sporting event } \\
\text { - Instability usually lasts three to five days after a } \\
\text { concussion occurs }\end{array}$ \\
\hline $\begin{array}{l}\text { Sideline assessment tools } \\
\text { SAC } \\
\text { SCAT } \\
\text { SCAT2 }\end{array}$ & $\begin{array}{l}\text { - A single, simple tool to assess a variety of domains in } \\
\text { the initial concussion assessment } \\
\text { - } \quad \text { Often used to monitor the recovery process } \\
\text { SAC can be used immediately after injury to evaluate } \\
\text { orientation, memory, concentration, and delayed } \\
\text { recall; validated as a sideline tool for athletes junior } \\
\text { high school-aged and older; emergency department } \\
\text { version is validated in adults } \\
\text { SCAT2 combines multiple assessment tools (symptom } \\
\text { checklist, concentration and memory tasks [Maddock's } \\
\text { questions], SAC, BESS, and Glasgow Coma Scale); } \\
\text { it is not validated but is widely used and the most } \\
\text { sophisticated sideline tool available }\end{array}$ \\
\hline $\begin{array}{l}\text { BESS = Balance Error Scoring System; SAC = } \\
\text { Standardized Assessment of Concussion; }\end{array}$ & $\begin{array}{l}\text { SCAT }=\text { Sport Concussion Assessment Tool; SOT }=\text { Sensory } \\
\text { Organization Test. }\end{array}$ \\
\hline
\end{tabular}

Table 2: Common tools to examine concussion along with their characteristics. 26

\section{CIS Management at the field}

When an athlete sustains an injury then the medical professional, trainer or coach should immediately examine with one of the CIS assessment tools. If it suspected the athlete should be bared from further play and continuous observation should be done and the index of medical center referral or neuroimaging should be kept low. Unless the symptoms have remitted they should not be allowed to return to sports.

\section{Treatment of CIS}

All CIS athletes are followed with a graduated play protocol each step of which requires 24 hours. At the end 


\section{Roka et al}

Indications for Neuroimaging
Guidelines from the American College of Emergency Physicians
Imaging is indicated in patients with a loss of consciousness or amnesia if at least one of the following is present: head-
ache (diffuse), vomiting, age older than 60 years, intoxication, deficits in short-term memory, evidence of trauma above
the clavicle, seizures, GCS score of less than 15, focal neurologic deficits, coagulopathy.
Imaging is indicated in patients with no loss of consciousness or amnesia if at least one of the following is present: focal
neurologic deficit, vomiting, severe headache, age older than 65 years, signs of basilar skull fracture, GCS score of less
than 15, coagulopathy, significant mechanism of injury (e.g., ejection from vehicle, pedestrian struck by vehicle, fall
from a height greater than 3 ft or five stairs).
Guidelines from the American Academy of Pediatrics and the American Academy of Family Physicians
Perform imaging in patients with loss of consciousness of greater than 60 seconds, evidence of skull fracture, or focal
neurologic findings.
Consider imaging or observation if patient has brief loss of consciousness.
Note that nonspecific signs (e.g., immediate seizures, headache, vomiting, lethargy) increase the likelihood of intracra-
nial injury, but have very limited predictive value.

the athlete needs a detailed checkup and then only allowed to play (Table 4). ${ }^{17}$ recent studies with functional MRI has shown that even with minor head injury players can have abnormal neuropsychological results which are called as subconcussion that can progress to chronic traumatic encephalopathy. ${ }^{3}$ Although well documented for adults the efficacy of this graduated scale is unknown in younger children.

There are no medications for CIS and most are used for symptomatic treatment of headache, nausea, vomiting, sleep disturbances or psychological problems. Rehabilitation, Buffalo concussion treadmill test, aerobics, exercises may be beneficial in CIS. ${ }^{22}$

\section{Recovery in CIS $^{22}$}

The definition of recovery is ill defined for CIS with delayed recovery upto a month after injury. The cognitive or academic recovery may take time and needs to be further studied. $15 \%$ of the athletes may return to play within one day and the same number took a month to return across younger age, high school and college groups. Adolescents may have longer recovery from CIS leading to altered academic performance which may suggest the younger brain may be more susceptible to injury. All aspects of the athlete's activity including, school, work, and daily activities must be assessed thoroughly before release from medical care. Neuropsychological, neurocognitive, motor, balance and physical examination must be made to avoid missing important signs of CIS.

\section{Concussion awareness and education}

All the sports can lead to CIS injury and awareness and education for the athlete, coach, organization, family and schools is important to avoid this injury. Some sports like football which has heading as part of the game it is difficult to control impact injury and presently there are no devices available to protect form CIS. Protective equipment like helmets, padding and covers can theoretically lower the risk of CIS injuries by $85 \%$ if it is worn properly. Children must always be supervised, rules of the game or the pool or outdoor park must be followed, and diving is discouraged in less than 12 feet deep pool/river/ponds. Avoid sports if ill, be aware of neighboring players and proper maintenance of the equipment can reduce injuries. Use of alcohol or other neuro depressant medication is to be banned and seat belts must be worn in all high speed activities. Few studies have though shown no benefit of using helmets to prevent concussion, subconcussion or rotational injuries and thus strict rules implementation, avoidance of impact, preventing fights or collision can reduce CIS injuries. ${ }^{26}$

Education and awareness training including information on the risk of each sportis important not only to the athletes and the coach but also to the public. Teaching should be started as a curriculum in schools regarding the dangers of concussion and the importance of safe play will definitely help to reduce CIS injuries. The coach and the supporting team must be regularly appraised regarding new developments in the management of concussion.

\section{Current and future research}

Although much has been studied in CIS pathology yet its exact cause remains unknown. Future studies in animal models and artificial dummy models could help prevent CIS injuries. ${ }^{1,7}$ The current research of MRI on 


\begin{tabular}{|c|c|c|c|c|c|}
\hline $\begin{array}{l}\text { Organisation, } \\
\text { year published }\end{array}$ & Definition of concussion & Domains assessed & Key features & $\begin{array}{l}\text { Definition mTBI? } \\
\text { Link concussion } \\
\text { - TB? }\end{array}$ & Notes \\
\hline $\begin{array}{l}\text { Concussion in } \\
\text { sports group, } \\
\text { 21-30 } \\
2002,2005 \text {, } \\
2009,2013\end{array}$ & $\begin{array}{l}\text { 'A complex pathophysiological process affecting the } \\
\text { brain, induced by traumatic biomechanical forces' that } \\
\text { 'may be caused by a direct blow to the head, face, } \\
\text { neck or elsewhere in the body with an impulsive force } \\
\text { transmitted to the head'. } \\
\text { Common features include: } \\
\text { Rapid onset of short-lived impairment of neurological } \\
\text { function that resolves spontaneously } \\
\text { May result in neuropathological changes, but the } \\
\text { acute clinical symptoms largely reflect a functional } \\
\text { disturbance rather than a structural injury } \\
\text { Graded set of neurological syndromes that may or } \\
\text { may not imolve an LoC. Resolution of the clinical and } \\
\text { cognitive features typically follows a sequential course. } \\
\text { In some cases symptoms may be prolonged. } \\
\text { Typically associated with grossly normal structural } \\
\text { neuroimaging studies. }\end{array}$ & $\begin{array}{l}\text { Clinical symptoms } \\
\text { (physical, } \\
\text { cognitive, } \\
\text { emotional) } \\
\text { Physical signs } \\
\text { Cognitive } \\
\text { impairment } \\
\text { Neurobehavioural } \\
\text { features } \\
\text { Sleep disturbances } \\
\end{array}$ & $\begin{array}{l}\text { Onset: rapid } \\
\text { Duration: short-liwed } \\
\text { Mechanism of impaimment: } \\
\text { functional disturbance rather } \\
\text { than structural injury } \\
\angle O C \text { : may or may not } \\
\text { Resolution: sequential } \\
\text { Neuroimaging. no abnormalities } \\
\text { on standard structural } \\
\text { neuroimaging }\end{array}$ & $\begin{array}{l}\text { No (concussion is } \\
\text { considered as subset } \\
\text { of TBI) }\end{array}$ & $\begin{array}{l}\text { This definition } \\
\text { also comments } \\
\text { on typical } \\
\text { neuroimaging } \\
\text { features in } \\
\text { concussion. }\end{array}$ \\
\hline $\begin{array}{l}\text { American } \\
\text { Medical Society } \\
\text { for Sports } \\
\text { Medicine, } \\
2013\end{array}$ & $\begin{array}{l}\text { 'A concussion is defined as at traumatically induced } \\
\text { transient disturbance of brain function and is caused by } \\
\text { a complex pathophysiological process. Concussions have } \\
\text { also been referred to as mild traumatic brain injuries } \\
\text { (mTBD). While all concussions are mTBls, not all mTBls } \\
\text { are concussions. Concussions are a subset of mTBls, on } \\
\text { the less-severe end of the brain injury spectrum and are } \\
\text { generally self-limited in duration and resolution'. }\end{array}$ & $\begin{array}{l}\text { Symptoms and } \\
\text { signs (physical, } \\
\text { cognitive, } \\
\text { emotional, sleep) }\end{array}$ & $\begin{array}{l}\text { Onset: not specified } \\
\text { Duration: transient, self-limited } \\
\text { Mechanism of impaiment: } \\
\text { functional disturbance } \\
\text { LOC: may or may not } \\
\text { Resolution: not specified } \\
\text { Neuroimaging: not specified }\end{array}$ & $\begin{array}{l}\text { No (concussion is } \\
\text { considered as subset } \\
\text { of mTBi) }\end{array}$ & \\
\hline $\begin{array}{l}\text { National } \\
\text { Athletic Trainers" } \\
\text { Association, } \\
\text { 2004, } 2014\end{array}$ & $\begin{array}{l}\text { 'Trauma-induced alteration in mental status that may or } \\
\text { may not involve loss of consciousness' }\end{array}$ & Not specified & $\begin{array}{l}\text { Onset: not specified } \\
\text { Duration: not specified } \\
\text { Mechanism of impaiment: not } \\
\text { specified } \\
\text { LOC: may or may not } \\
\text { Resolution: not specified } \\
\text { Neuroimaging: not specified }\end{array}$ & $\begin{array}{l}\text { No (concussion } \\
\text { and mTBI are used } \\
\text { interchangeably) }\end{array}$ & \\
\hline $\begin{array}{l}\text { American } \\
\text { Academy of } \\
\text { Neurology, } 3246 \\
1997,2013\end{array}$ & $\begin{array}{l}\text { 'Concussion is a trauma-induced alteration in mental } \\
\text { status that may or may not involve loss of consciousness. } \\
\text { Confusion and amnesia are the hallmarks of concussion. } \\
\text { The confusional episode and amnesia may occur } \\
\text { immediately after the blow to the head or several } \\
\text { minutes later'. }\end{array}$ & $\begin{array}{l}\text { Clinical symptoms } \\
\text { (physical } \\
\text { cognitive, } \\
\text { emotional) } \\
\text { Physical signs } \\
\text { Cognitive } \\
\text { impairment } \\
\text { Sleep disturbances }\end{array}$ & $\begin{array}{l}\text { Onset: immediate or within mins } \\
\text { Duration: not specified } \\
\text { Mechanism of impaiment: not } \\
\text { specified } \\
\text { LOC: may or may not } \\
\text { Resolution: not specified } \\
\text { Heuroimaging. not specified }\end{array}$ & $\begin{array}{l}\text { No (concussion } \\
\text { and mTBI are used } \\
\text { interchangeably) }\end{array}$ & $\begin{array}{l}1997 \text { definition } \\
\text { was used as the } \\
2013 \text { revision } \\
\text { provided a } \\
\text { shortened } \\
\text { definition only. }\end{array}$ \\
\hline $\begin{array}{l}\text { Team Physician } \\
\text { Consensus } \\
\text { statements } \\
\text { (AAFP, AAOS, } \\
\text { ACSM, AMSSM, } \\
\text { AOSSM, } \\
\text { AOASM) }{ }^{35} 36 \\
\text { 2006, } 2011\end{array}$ & $\begin{array}{l}\text { 'Concussion or mild traumatic brain injury (mTBI) is a } \\
\text { pathophysiological process affecting the brain induced by } \\
\text { direct or indirect biomechanical forces'. } \\
\text { Common features include: } \\
\text { Rapid onset of usually short-lived neurological } \\
\text { impairment, which typically resolves spontaneously } \\
\text { Acute dinical symptoms that usually reflect a } \\
\text { functional disturbance rather than structural injury } \\
\text { A range of dinical symptoms that may or may not } \\
\text { inwolve LOC }\end{array}$ & $\begin{array}{l}\text { Clinical } \\
\text { symptoms and } \\
\text { signs (cognitive, } \\
\text { somatic, affective, } \\
\text { sleep disturbances) }\end{array}$ & $\begin{array}{l}\text { Onset: rapid } \\
\text { Duration: short-liwed } \\
\text { Mechanism of impaiment: } \\
\text { functional disturbance rather } \\
\text { than structural injury } \\
\text { LOC: may or may not } \\
\text { Resolution: spontaneous } \\
\text { Weuroimaging- no abnormalities } \\
\text { on standard structural } \\
\text { neuroimaging }\end{array}$ & $\begin{array}{l}\text { Combined definition } \\
\text { for mTBI and } \\
\text { concussion }\end{array}$ & $\begin{array}{l}\text { This definition } \\
\text { also comments } \\
\text { on typical } \\
\text { neuroimaging } \\
\text { features in } \\
\text { concussion. }\end{array}$ \\
\hline $\begin{array}{l}\text { Congress of } \\
\text { Neurological } \\
\text { Surgeons, } \\
1966\end{array}$ & $\begin{array}{l}\text { 'a clinical syndrome characterized by the immediate and } \\
\text { transient post-traumatic impairment of neural function } \\
\text { such as alteration of consciousness, disturbance of vision } \\
\text { or equilibrium due to mechanical forces.' }\end{array}$ & Not specified & $\begin{array}{l}\text { Onset: immediate } \\
\text { Duration: transient } \\
\text { Mechanism of impaiment: not } \\
\text { specified } \\
\text { LOC: may or may not } \\
\text { Resolution: not specified } \\
\text { Neurowmaging: not specified }\end{array}$ & Not specified & \\
\hline
\end{tabular}

"In case of revised concussion definitions from the same group, the most recent version was considered if not stated otherwise.

AAFP, American Academy of Family Physicians, AAOS, American Academy of Orthopaedic Surgeons; ACSM, American College of Sports Medicine, AMSSM, American Medical Society for Sports Medicine; AOSSM, American Orthopaedic Society for Sports Medicine; AOASM, American Osteopathic Academy of Sports Medicine; LOC, loss of consciousness, $\mathrm{mTB}$, mild traumatic brain injury.

Figure 1: Definition of different bodies of Concussion. 


\section{Roka et al}

\begin{tabular}{|l|l|l|}
\hline Rehabilitation stage & $\begin{array}{l}\text { Functional exercise at each stage of } \\
\text { rehabilitation }\end{array}$ & Objective(s) of each stage \\
\hline 1. No activity & Symptom-limited physical and cognitive rest & Recovery \\
\hline 2. Light aerobic exercise & $\begin{array}{l}\text { Walking, swimming, or stationary cycling, } \\
\text { keeping intensity, 70\% of maximum permit- } \\
\text { ted heart rate; no resistance training }\end{array}$ & Increase heart rate \\
\hline 3. Sport specific exercise & $\begin{array}{l}\text { Skating drills in ice hockey, running drills in } \\
\text { soccer; no head-impact activities }\end{array}$ & Add movement \\
\hline 4. Noncontact training drills & $\begin{array}{l}\text { Progression to more complex training drills, } \\
\text { e.g., passing drills in football and ice hockey; } \\
\text { may start progressive resistance training }\end{array}$ & $\begin{array}{l}\text { Exercise, coordination, and cognitive } \\
\text { load }\end{array}$ \\
\hline 5. Full-contact practice & $\begin{array}{l}\text { After medical clearance, participation in } \\
\text { normal training activities }\end{array}$ & $\begin{array}{l}\text { Restore confidence and assessment of } \\
\text { functional skills by coaching staff Return } \\
\text { to play Normal game play }\end{array}$ \\
\hline
\end{tabular}

Table 4. The graduated return to play protocol.17

subconcussion and in specific cohorts of athletes can help increase our knowledge of CIS.

\section{Summary}

CIS is a complex injury the pathogenesis of which is yet to be fully understood. If not recognized early, it can lead to disastrous consequences including death. The entire supporting team should be aware of such injury and it clinical manifestations which if suspected the athlete must be barred from further play and given medical care. Recovery must be closely followed in a graduated step wise manner and made clear not to take part in physical impact sports. Proper education of the public, precautions taken during sports can help reduce CIS injury.

\section{References:}

1. Angoa-Pérez M, Kane MJ, Briggs DI, HerreraMundo N, Viano DC, Kuhn DM: Animal models of sportsrelated head injury: bridging the gap between preclinical research and clinical reality. $\mathbf{J}$ Neurochem 129: 916-931, 2014

2. Aubry M, Cantu R, Dvorak J, et al. Summary and agreement statement of the First International Conference on Concussion in Sport, Vienna 2001. Recommendations for the improvement of safety and health of athletes who may suffer concussive injuries. Br J Sports Med 36:6-10, 2002

3. Bailes JE, Petraglia AL, Omalu BI, Nauman E, Talavage T: Role of subconcussion in repetitive mild traumatic brain injury. J Neurosurg 119: 1235-1245, 2013

4. Bakhos LL, Lockhart GR, Myers R, Linakis JG. Emergency department visits for concussion in young child athletes. Pediatrics 126 (3): e550-e556, 2010

5. Castile L, Collins CL, McIlvain NM, Comstock RD. The epidemiology of new versus recurrent sports concussions among high school athletes, 2005-2010. Br J Sports Med 46 (8):603-10, 2012

6. Dick RW. Is there a gender difference in concussion incidence and outcomes? Br J Sports Med 43 (suppl 1):i46-i50, 2009

7. Giza CC, Kutcher JS, Ashwal S, Barth J, Getchius TS, Gioia GA, Gronseth GS, Guskiewicz K, Mandel S, Manley G, McKeag DB, Thurman DJ, Zafonte R: Summary of evidence-based guideline update: evaluation and management of concussion in sports: report of the Guideline Development Subcommittee of the American Academy of Neurology. Neurology 80: $2250-2257,2013$

8. Gold EM, Vasilevko V, Hasselmann J, Tiefenthaler C, Hoa D, Ranawaka K, Cribbs DH, Cummings BJ. Repeated Mild Closed Head Injuries Induce LongTerm White Matter Pathology and Neuronal Loss That Are Correlated With Behavioral Deficits. ASN Neuro 10:1759091418781921, 2018

9. Halstead ME, Walter KD; Council on Sports Medicine and Fitness. American Academy of Pediatrics. Clinical report — sport-related concussion in children 
and adolescents. Pediatrics 26 (3):597-615, 2010

10. Harmon KG, Drezner JA, Gammons M, Guskiewicz KM, Halstead M, Herring SA, Kutcher JS, Pana A, Putukian M, Roberts WO. American Medical Society for Sports Medicine position statement: concussion in sport. Br J Sports Med 47 (1):15-26, 2013

11. Jagoda AS, Bazarian JJ, Bruns JJ Jr, et al.; American College of Emergency Physicians; Centers for Disease Control and Prevention. Clinical policy: neuroimaging and decisionmaking in adult mild traumatic brain injury in the acute setting. Ann Emerg Med 52 (6): 714-748, 2008

12. Kawata K, Mitsuhashi M, Aldret R. A Preliminary Report on Brain-Derived Extracellular Vesicle as Novel Blood Biomarkers for Sport-Related Concussions. Front Neurol 12;9:239, 2018

13. Kerr ZY, Zuckerman SL, Register-Mihalik JK, Wasserman EB, Valovich McLeod TC, Dompier TP, Comstock RD, Marshall SW. Estimating Concussion Incidence Using Sports Injury Surveillance Systems: Complexities and Potential Pitfalls. Neurol Clin 35(3):409-434, 2017

14. Kirkwood MW, Yeates KO, Wilson PE. Pediatric sport-related concussion: a review of the clinical management of an oft-neglected population. Pediatrics 117 (4):1359-1371, 2006

15. McCrory $\mathrm{P}$, Feddermann-Demont $\mathrm{N}$, Dvořák $\mathrm{J}$, Cassidy JD, McIntosh A, Vos PE, Echemendia RJ, Meeuwisse W, Tarnutzer AA. What is the definition of sports-related concussion: a systematic review. $\mathbf{B r}$ J Sports Med 51 (11):877-887, 2017

16. McCrory PR, Berkovic SF. Concussion: the history of clinical and pathophysiological concepts and misconceptions. Neurology 57:2283-9, 2001

17. Mizobuchi Y, Nagahiro S. A Review of Sport-Related Head Injuries. Korean Journal of Neurotrauma 12 (1): 1-5, 2016
18. Patel DR, Reddy V. Sport-related concussion in adolescents. Pediatr Clin North Am 57 (3):649 670, 2010

19. Patricios J, Fuller GW, Ellenbogen R, et al. What are the critical elements of sideline screening that can be used to establish the diagnosis of concussion? A systematic review. Br J Sports Med :bjsports-2016097441-894, 2017

20. Pearce JM. Observations on concussion. A review. Eur Neurol 2008;59(3-4):113-9.

21. Prien A, Grafe A, Rössler R, Junge A, Verhagen E. Epidemiology of Head Injuries Focusing on Concussions in Team Contact Sports: A Systematic Review. Sports Med 48 (4):953-969, 2018

22. Register-Mihalik JK, Kay MC. The Current State of Sports Concussion. Neurol Clin 35 (3):387-402, 2017

23. Rhazes A. Lutetiaeexofficina. Rome, Italy: Stephan, R, 1548

24. Saunders RL, Harbaugh RE. The second impact in catastrophic contact-sports head trauma. JAMA 252 (4):538-9, 1984

25. SchneiderR.Head and neckinjuries in football 1: mechanisms, treatment, and prevention. Baltimore: Williams \& Wilkins Co; 1973

26. Scorza KA, Raleigh MF, O'Connor FG. Current concepts in concussion: evaluation and management. Am Fam Physician15;85 (2):123-32, 2012

27. Steenerson K, Starling AJ. Pathophysiology of Sports-Related Concussion. Neurol Clin35 (3):403408, 2017

28. The management of minor closed head injury in children. Committee on Quality Improvement, American Academy of Pediatrics. Commission on Clinical Policies and Research, American Academy of Family Physicians. Pediatrics 104 (6):1407-1415, 1999 